\title{
Antibody Cocktail Exhibits Broad Neutralization Activity Against SARS- CoV-2 and SARS-CoV-2 Variants
}

\author{
Yuanyuan $\mathrm{Qu}^{1} \cdot$ Xueyan Zhang ${ }^{2,7} \cdot$ Meiyu Wang ${ }^{3,8} \cdot$ Lina Sun $^{1} \cdot$ Yongzhong Jiang ${ }^{4} \cdot$ Cheng $\mathrm{Li}^{5} \cdot$ \\ Wei $\mathrm{Wu}^{1} \cdot$ Zhen $\mathrm{Chen}^{2} \cdot$ Qiangling $\mathrm{Yin}^{1} \cdot$ Xiaolin Jiang ${ }^{6} \cdot$ Yang Liu ${ }^{1} \cdot$ Chuan $\mathrm{Li}^{1} \cdot$ Jiandong $\mathrm{Li}^{1}$. \\ Tianlei Ying ${ }^{5}$ Dexin $\mathrm{Li}^{1} \cdot$ Faxian $\mathrm{Zhan}^{4} \cdot$ Youchun Wang $^{3,8} \cdot$ Wuxiang Guan $^{2}$ (1) - Shiwen Wang ${ }^{1}$ (1) \\ Mifang Liang ${ }^{1}$
}

Received: 16 March 2021 / Accepted: 6 May 2021 / Published online: 5 July 2021

(c) Wuhan Institute of Virology, CAS 2021

\begin{abstract}
Severe acute respiratory syndrome coronavirus 2 (SARS-CoV-2) has precipitated multiple variants resistant to therapeutic antibodies. In this study, 12 high-affinity antibodies were generated from convalescent donors in early outbreaks using immune antibody phage display libraries. Of them, two RBD-binding antibodies (F61 and H121) showed high-affinity neutralization against SARS-CoV-2, whereas three S2-target antibodies failed to neutralize SARS-CoV-2. Following structure analysis, F61 identified a linear epitope located in residues G446-S494, which overlapped with angiotensinconverting enzyme 2 (ACE2) binding sites, while H121 recognized a conformational epitope located on the side face of RBD, outside from ACE2 binding domain. Hence the cocktail of the two antibodies achieved better performance of neutralization to SARS-CoV-2. Importantly, these two antibodies also showed efficient neutralizing activities to the variants including B.1.1.7 and B.1.351, and reacted with mutations of N501Y, E484K, and L452R, indicated that it may also neutralize the recent India endemic strain B.1.617. The unchanged binding activity of F61 and H121 to RBD with multiple mutations revealed a broad neutralizing activity against variants, which mitigated the risk of viral escape. Our findings revealed the therapeutic basis of cocktail antibodies against constantly emerging SARS-CoV-2 variants and provided promising candidate antibodies to clinical treatment of COVID-19 patients infected with broad SARS-CoV-2
\end{abstract} variants.

Yuanyuan Qu, Xueyan Zhang, Meiyu Wang, Lina Sun contributed equally to this work.

Supplementary Information The online version contains supplementary material available at https://doi.org/10.1007/s12250021-00409-4.

Shiwen Wang

wangsw@ivdc.chinacdc.cn

$\triangle$ Mifang Liang

liangmf@ivdc.chinacdc.cn

$\bowtie$ Wuxiang Guan

guanwx@wh.iov.cn

1 State Key Laboratory for Molecular Virology and Genetic Engineering, National Institute for Viral Disease Control and Prevention, Chinese Center for Disease Control and Prevention, Beijing 102206, China

2 Center for Emerging Infectious Diseases, Wuhan Institute of Virology, Chinese Academy of Sciences,

Wuhan 430071, Hubei, China
Keywords Antibody cocktail - Severe acute respiratory syndrome coronavirus 2 (SARS-CoV-2) · Broad neutralization · SARS-CoV-2 variants · Angiotensinconverting enzyme 2 (ACE2)
3 Division of HIV/AIDS and Sex-Transmitted Virus Vaccines, Institute for Biological Product Control, National Institutes for Food and Drug Control (NIFDC), Beijing 102629, China

4 Hubei Provincial Center for Disease Control and Prevention, Wuhan 430065, China

5 Key Laboratory of Medical Molecular Virology (MOE/NHC/ CAMS), School of Basic Medical Sciences, Fudan University, Shanghai 200032, China

6 Shandong Center for Disease Control and Prevention, Jinan 250014, China

7 University of Chinese Academy of Sciences, Beijing 100049, China

8 Peking Union Medical College, Beijing 100730, China 


\section{Introduction}

Severe acute respiratory syndrome coronavirus 2 (SARS$\mathrm{CoV}-2)$ is acknowledged as the novel coronavirus that causes the global pandemic of COVID-19. Up to 4 May 2021, over 155 million confirmed cases have been reported worldwide (WHO 2021). SARS-CoV-2 grouped to the Betacoronavirus genus (Zhou et al. 2020) is proved to share about $80 \%$ sequence identity to SARS-CoV and target the same cellular receptor, angiotensin-converting enzyme 2 (ACE2) (Wrapp et al. 2020). SARS-CoV-2 spike (S) protein, which is consisted of S1 subunit and S2 subunit, can directly bind to ACE2 and mediate virus entry into cells (Wrapp et al. 2020).

To date, a variety of neutralizing antibodies against SARS-CoV-2 S protein has been generated. Potent neutralizing often found to target S1 subunit (Hwang et al. 2006), which consists of the N-terminal domain (NTD) and the receptor-binding domain (RBD). However, neutralizing antibodies targeting the S2 subunit still need to be developed (Liu et al. 2020; Wec et al. 2020). The NTD-specific monoclonal antibodies (mAbs) target a patch remote from RBD (Chi et al. 2020; Liu et al. 2020). RBD-specific mAbs are divided into four main classes (Barnes et al. 2020). Antibodies grouped in class one and class two, such as CB6 (Shi et al. 2020) and P2B-2F6 (Ge et al. 2021), are found with high potencies and overlapped with the receptorbinding motif (RBM) on RBD (Ju et al. 2020; Shi et al. 2020; Wu et al. 2020). These mAbs are dominant in convalescent serum (Piccoli et al. 2020). Antibodies in the third and fourth class, like S309 (Pinto et al. 2020) and CR3022 (Piccoli et al. 2020; Xiang et al. 2020), are positioned detached from the RBM (Starr et al. 2020).

The rapid global spread and transmission of SARSCoV-2 are hypothesized to provide the virus with substantial opportunities for the natural selection of favorable mutations, many of which involved modification of $\mathrm{S}$ protein. The D614G mutation in the S protein enhances viral transmission and overtakes the prime strain of SARSCoV-2 (Zhang et al. 2020; Li et al. 2021). The recent emerging variants of concern observed in the United Kingdom (B.1.1.7 with mutations N501Y, A570D and del69/70), South Africa (B.1.351 with mutations K417N, E484K and N501Y), Brazil (P.1 and P.2 with mutations K417T, E484K and N501Y) (Long et al. 2021) and India (B.1.617 with mutations L452R and E484Q) (Cherian et al. 2021) initially respond more tightly to ACE2 and appear to be more infectious to human (Laffeber et al. 2021; Tian et al. 2021). More severely, B.1.351 and P.1 are resistant to convalescent plasma, vaccine sera, and multiple neutralizing mAbs (Hoffmann et al. 2021; Widera et al. 2021), while B.1.617 can be neutralized by convalescent sera and vaccine sera of BBV152 (Covaxin) (Yadav et al. 2021). Variants B.1.141 and B.1.258 with mutation N439K increase spike affinity for ACE2 and confer resistance to several mAbs (Thomson et al. 2021). American variants (B.1.429 and B.1.427) containing L452R (Long et al. 2021) show refractory to mAbs as well. SARS-CoV-2 variants isolated from minks and mouse harboring mutations G261D, A262S, L452M, Y453F, F486L, Q498H and N501T may cause potential cross-species transmission that worth closely monitor (Thomson et al. 2021; Yao et al. 2021). Thus, it is essential to develop antibodies with broad-spectrum activities against SARS-CoV-2 and SARS$\mathrm{CoV}-2$ variants.

A variety of neutralizing antibodies against SARS-CoV2 have entered clinical trials. However, the virus may persist due to mutations, especially mutations on the $\mathrm{S}$ protein, leading to dropping neutralizing activity and hence efficacy from these neutralizing antibodies in the longer term (Li et al. 2020). Therefore, it is essential to develop various neutralizing antibodies against different epitopes. Besides, novel delivery strategies of antibodies, such as antibody inhalation treatment, would be encouraged and benefit from the convenience and widely applied during COVID-19 prevention.

Here we reported $12 \mathrm{mAbs}$ screened with purified SARS-CoV-2 RBD, S1 and S2 from three COVID-19 convalescent patients by phage antibody library technique. Then we characterized their affinity, neutralizing activity, and binding sites. We also evaluated the neutralizing activity of screened mAbs to the SARS-CoV-2 variants. Additionally, we selected two RBD-specific antibodies (F61 and H121) with high neutralizing activity and high affinity to investigate the interaction between antibodies and RBD via computer simulation. Our research provided a theoretical basis for the development of therapeutic antibodies.

\section{Materials and Methods}

\section{Cells and Viruses}

Cell lines (HEK293T and Vero E6 cells) were initially acquired from the American Type Culture Collection (ATCC; USA). EXPi293F cells were purchased from Life Technologies, USA. They were cultured at $37{ }^{\circ} \mathrm{C}$ under $5 \%$ $\mathrm{CO}_{2}$ in Dulbecco's modified Eagle's medium (DMEM; Life Technologies, USA) supplemented with $10 \%$ heatinactivated fetal bovine serum (FBS; Life Technologies, USA) and $1 \%$ penicillin/streptomycin (Life Technologies, USA) or in EXPI293 expression medium (Life Technologies, USA). Cells were passaged every two days and digested with $0.05 \%$ trypsin-EDTA. Pseudovirus of SARS- 
CoV-2 (GenBank: MN908947) and SARS-CoV-2 variants were obtained from the National Institutes for Food and Drug Control. The authentic SARS-CoV-2 (GenBank: MN908947) and SARS-CoV-2 variants were obtained from the Wuhan Institute of Virology. All work with infectious SARS-CoV-2 was performed in the Institutional Biosafety Committee approved BSL3 facilities using appropriate positive pressure air respirators and protective equipment.

\section{Construction and Screening of Human Antibody Phage Display Library}

The procedures of phage display library in the vector pComb $3 \mathrm{H}$ followed the methods described previously (Kashyap et al. 2008). Briefly, lymphocytes were isolated from three convalescent donors in early outbreaks which were selected by Enzyme-Linked Immunosorbent (ELISA) assays and colloidal gold test (INNOVITA, China). Total cellular mRNA was extracted using the RNeasy Mini kit (Qiagen, Germany), and cDNA was synthesized with primer oligo (dT) using Transcriptor High Fidelity cDNA Synthesis kit (Roche, Switzerland). PCR amplification was then performed using FastStrat High Fidelity PCR System (Roche, Switzerland). The light and heavy chain genes were amplified from the cDNA by PCR using the primer pairs from $V K, V L$ and $V H$ gene families, then cloned into the vector pComb 3H (Barbas et al. 1991). The library's initial diversity was evaluated and assured by sequencing of randomly picked clones for each step of library construction and the complexity of the library was then calculated. The final yielded antibody libraries were panned and screened with purified SARS-CoV-2 RBD protein, S1 protein and S2 protein (Jiangsu East-Mab Biomedical Technology, China) following the standard panning procedure (Barbas and Burton 1996).

\section{Production of Monoclonal Antibody}

For recombinant human mAb production, the cDNA encoding $\mathrm{mAb}$ variable regions of the heavy and light chains were cloned into expression plasmids containing the human IgG1 heavy chain and Ig kappa or lambda light chain constant regions, respectively. Recombinant mAbs were then produced in EXPi293F cells (Life Technologies, USA) by transfecting pairs of the IgG1 heavy and light chain expression plasmids. Human antibodies purified by Protein-G (GE Healthcare, USA) affinity chromatography were stored at $-80{ }^{\circ} \mathrm{C}$ until use.

\section{Enzyme-Linked Immunosorbent (ELISA) Assays and Non-Competitive ELISA Assay}

ELISA plates were coated with SARS-CoV-2 RBD protein, $\mathrm{S} 1$ protein, $\mathrm{S} 2$ protein, $\mathrm{S}$ protein trimer, and mutant $\mathrm{S} 1$ protein (Jiangsu East-Mab Biomedical Technology, China) at $4{ }^{\circ} \mathrm{C}$ overnight. Following washing with PBST, serial dilutions of testing antibodies start at $1 \mu \mathrm{g} / \mathrm{mL}$ or serial dilutions of plasma start at 1:100 were added to each well and incubated at $37{ }^{\circ} \mathrm{C}$ for $30 \mathrm{~min}$. After washing with PBST, horseradish peroxidase (HRP)-conjugated anti-human IgG antibody (Sigma, USA) was added at the dilution of 1:20,000 and incubated at $37{ }^{\circ} \mathrm{C}$ for $30 \mathrm{~min}$. The absorbance was detected at $450 \mathrm{~nm}$. The data were analyzed using GraphPad Prism 8.0.

\section{Surface Plasmon Resonance (SPR) Assay}

Purified antibodies targeting S1 were quantified with SPR assay using the BIAcore 8000 system (GE Healthcare, USA) carried out at $25{ }^{\circ} \mathrm{C}$ in single-cycle mode. Purified SARS-CoV-2 $\mathrm{S} 1$ diluted in $10 \mathrm{mmol} / \mathrm{L}$ sodium acetate buffer (pH 5.5) was immobilized to CM5 sensor chip by amine coupling reaction. Serially diluted antibodies were injected with a rate of $30 \mathrm{~mL} / \mathrm{min}$ in sequence. The equilibrium dissociation constants (binding affinity, $K_{D}$ ) for each antibody were calculated using Biacore 8000 Evaluation Software.

\section{Virus Neutralization Assay}

The virus neutralization assay with pseudoviruses was conducted as described previously (Nie et al. 2020). Briefly, serially diluted antibodies were added into 96-well plates. After that, $50 \mu \mathrm{L}$ pseudoviruses were added to the plates, followed by incubation at $37^{\circ} \mathrm{C}$ for one hour. Afterward, HuH-7 cells were added into the plates $\left(2 \times 10^{4}\right.$ cells $/ 100 \mu \mathrm{L}$ per well), followed by $24 \mathrm{~h}$ incubation at $37{ }^{\circ} \mathrm{C}$ in a humidified atmosphere with $5 \% \mathrm{CO}_{2}$. Chemiluminescence detection was performed straight after, and the Reed-Muench method was used to calculate the virus neutralization titer. The half-maximal inhibitory concentrations (IC50) were determined using 4-parameter logistic regression (GraphPad Prism version 8).

Authentic SARS-CoV-2 was used in the plaque reduction neutralization test (PRNT). In brief, the mAbs were trifold serially diluted in culture medium and mixed with SARS-CoV-2 (200 PFU) for one hour. Mixtures were then transferred to 24-well plates seeded with Vero E6 cells and allowed absorption for $1 \mathrm{~h}$ at $37{ }^{\circ} \mathrm{C}$. Inoculums were then removed before adding the overlay media $(100 \mu \mathrm{L}$ MEM containing $1 \%$ carboxymethylcellulose, CMC). The plates 
were then incubated at $37{ }^{\circ} \mathrm{C}$ for $96 \mathrm{~h}$. Cells were fixed with $4 \%$ paraformaldehyde solution for one day, and overlays were removed. Cells were incubated with $1 \%$ crystal violet for five minutes at room temperature. The half-maximal inhibitory concentrations (IC50) were determined using 4-parameter logistic regression (GraphPad Prism version 8).

\section{Fluorescence-Activated Cell Sorting (FACS) Assay}

SARS-CoV-2 S protein-expressing plasmids were transfected into HEK293T cells using Lipofectamine 3000 (Invitrogen, USA). $24 \mathrm{~h}$ after transfection, cells were suspended and washed with PBS twice. Then the cells were incubated with $20 \mu \mathrm{g} / \mathrm{mL}$ mAbs or isotype IgG mAb of hepatitis $\mathrm{b}$ virus (HBV), at room temperature for $1 \mathrm{~h}$, followed by further incubation with anti-human IgG FITCconjugated antibody (Sigma, USA). The cells were analyzed using FACSAria II (BD, USA). All of these data were analyzed using FlowJo.

The block assay was assessed by FACS. HEK293T cells were transiently transfected with the ACE2 expression plasmid for $24 \mathrm{~h}$. The mouse-Fc tag Fusion protein of SARS-CoV-2 RBD (RBD-mFC) (Jiangsu East-Mab Biomedical Technology,China) at a concentration of $2 \mu \mathrm{g} / \mathrm{mL}$ was mixed with the mAbs or isotype $\mathrm{IgG}$ at a molar ratio of $1: 10$ and incubated at $4{ }^{\circ} \mathrm{C}$ for $1 \mathrm{~h}$. Then mixtures were added to $2.5 \times 10^{5}$ HEK293T cells expressing ACE2 and incubated at $4{ }^{\circ} \mathrm{C}$ for another hour. Then cells were stained with anti-mouse IgG Taxes redconjugated antibody and anti-human IgG FITC-conjugated antibody (Sigma, USA) for another $30 \mathrm{~min}$ then analyzed by FACSAria II (BD, USA).

\section{Competition ELISA Assay}

Plates were coated with SARS-CoV-2 RBD (Jiangsu EastMab Biomedical Technology, CHN) at $4{ }^{\circ} \mathrm{C}$ overnight. Two-fold serial dilutions antibodies were added to the wells, and plates were incubated for one hour at $37^{\circ} \mathrm{C}$. Then plates were incubated with HRP-conjugated $\mathrm{mAb}$ (diluted 1:2000) (Wantai BioPharm, CHN) for $30 \mathrm{~min}$ at $37^{\circ} \mathrm{C}$. HRP activity was measured at $450 \mathrm{~nm}$. Paired antibodies with a value less than $20 \%$ were defined as noncompeting. Antibodies were deemed to compete for the same epitopes if the value was calculated greater than $60 \%$. Otherwise, if the value was found between $20 \%$ and $60 \%$, the antibody pairs were considered partially overlapping. The percent of binding inhibition of labeled antibodies was calculated according to the formula below:

$f=\frac{\mathrm{A}_{450}(\text { uninhibited })-\mathrm{A}_{450}(\text { inhibited })}{\mathrm{A}_{450}(\text { uninhibited })} \times 100$

\section{Molecular Modeling and Docking of the Antibodies to RBD}

The computational simulation was carried out by Discovery studio 2.0 (Accelrys, San Diego, CA) (Kaushik and Sowdhamini 2011). A suitable template was obtained through a BLAST search of the Protein Databank (PDB). The homology modeling of mAbs was performed using DS Homology Modeling protocol, and the 3D model of antibody was optimized using Antibody loop refinement protocol. The models were validated by Ramachandran plots. Protein-protein docking of RBD and mAbs was performed using the ZDOCK and RDOCK programs by specifying the variable region's antibody residues on the binding interface. RDOCK refinement was performed on the top 100 poses of the filtered ZDOCK output and applied scoring function to each docked structure for best binding models.

\section{Result}

\section{Generation and Screening of Antibodies Against SARS-CoV-2}

To isolate mAbs, we collected plasma and peripheral blood mononuclear cells (PBMCs) from 15 confirmed COVID-19 convalescent patients in Hubei and Shandong Province. We evaluated the titer of antibodies in plasma against SARSCoV-2 $\mathrm{N}$ protein and different fragments of $\mathrm{S}$ protein (including RBD, S1, and S2) with ELISA (Fig. 1A) and colloidal gold test (data not shown). The plasma from donors 2, 10 and 11 showed higher IgG titer against RBD, $\mathrm{S} 1$ and $\mathrm{S} 2$. Thus they were chosen for library construction by the pComb $3 \mathrm{H}$ vector system. The library was established with a complexity of $1 \times 10^{8}$ estimated independent clones and $100 \%$ Fab genes diversity after sequencing confirmation. Single clone screening was performed with ELISA, and a total of 274 positive monoclones were identified (Fig. 1B). Based on sequencing and ELISA results, four unique clones from RBD, five from S1, and three from S2 were chosen as the candidates for further interrogation.

To analyze the characteristics of selected Fab antibodies, we cloned the Fab antibodies into the IgG1 format. The binding specificity of the 12 candidate IgGs toward purified SARS-CoV-2 virion and different S protein fragments (S1, $\mathrm{S} 2, \mathrm{RBD}$, and $\mathrm{S}$ protein trimer) were further determined utilizing ELISA. All 12 antibodies were able to recognize the purified SARS-CoV-2 virion and S protein trimer. However, the binding strength of 12 antibodies to purified SARS-CoV-2 virion varied. A199, B15, H278, B120 and 
A

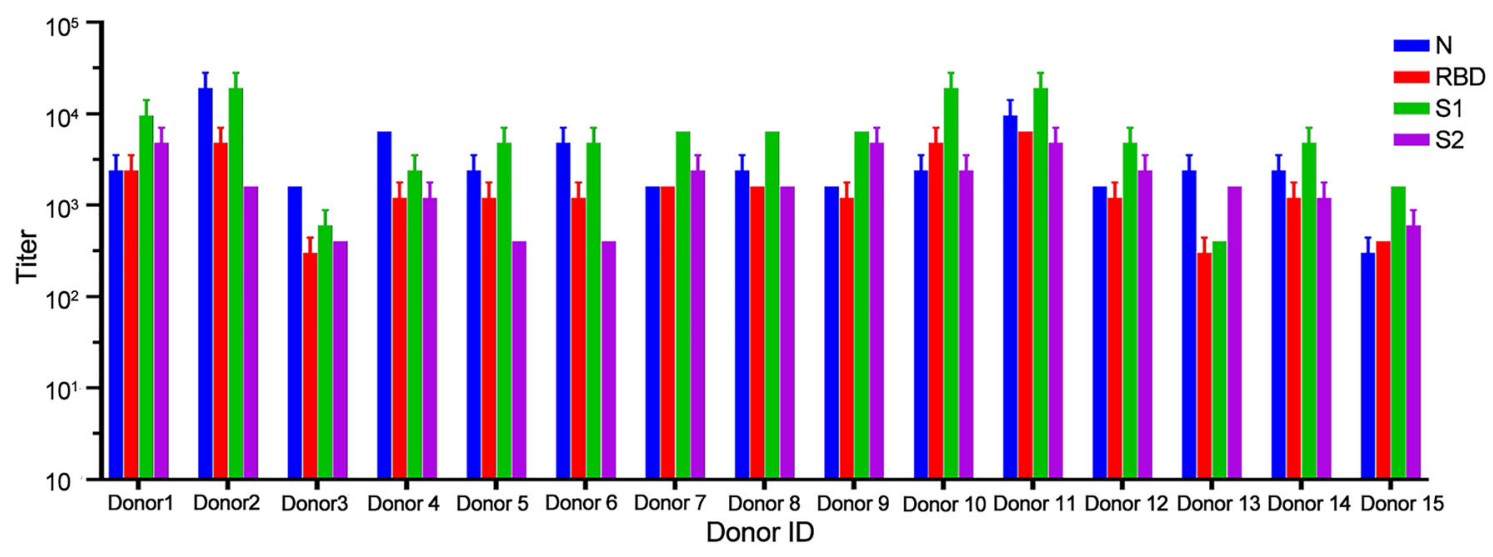

B

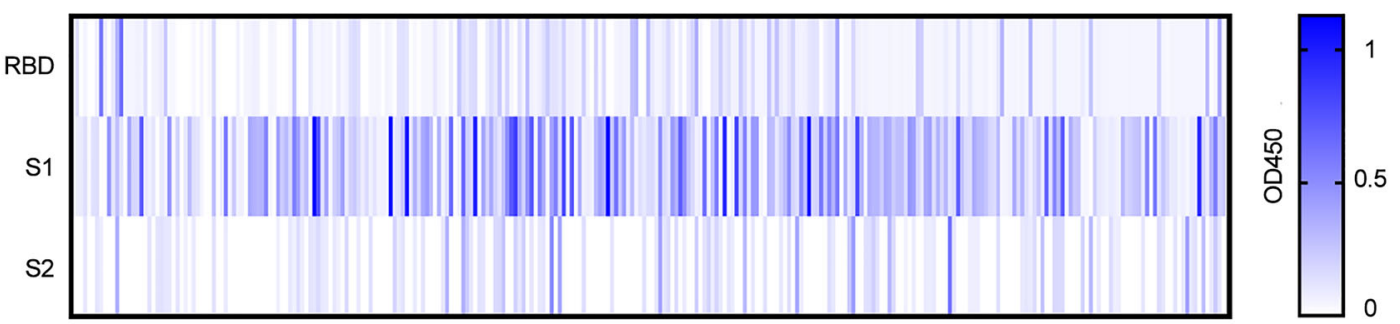

C
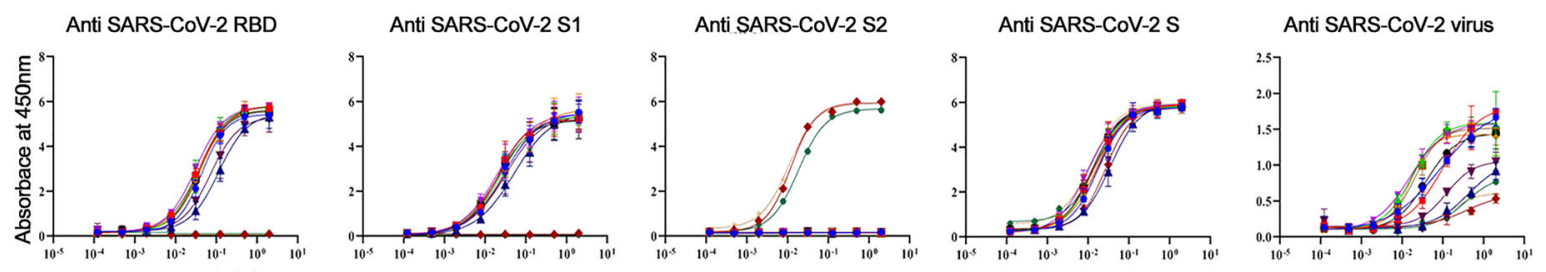

- F61

-F163

- H121

+ $\mathrm{C} 25$

- A8

- H184

를 $\mathrm{B} 110$

- A199

$\checkmark \mathrm{B} 15$

- H278

- B120

- H285

Fig. 1 Generation and screening of antibodies from SARS-CoV-2 convalescent patients. A Antibodies titer in the plasma of SARSCoV-2 convalescent patients to SARS-CoV-2 N protein and different fragments of SARS-CoV-2 S protein (RBD, S1, and S2). Experiments were performed in duplicate and the error bars denote $\pm \mathrm{SD}, \mathrm{n}=2$. B Heat-maps of Fab clones against RBD $(\mathrm{n}=288), \mathrm{S} 1$ protein

H285 had a weak affinity to virion. Nine antibodies (F61, F163, B15, H121, C25, A8, H184, B110 and A199) screened with purified RBD and S1 were all positive to RBD. The rest three of them (H278, B120 and H285) were found attached to S2 but not S1 nor RBD (Fig. 1C). NTD specific mAbs were not screened and identified.

\section{Characterizing the Binding Profile of 12 Candidate Antibodies}

The specificity of candidate SARS-CoV-2 specific IgGs was evaluated utilizing FACS. All candidate IgGs (labeled by FITC) showed positive on the surface of HEK293T cells expressing SARS-CoV-2 S protein. In contrast, HBV mAb, $(\mathrm{n}=288)$ and $\mathrm{S} 2$ protein $(\mathrm{n}=288)$. Each lattice represented a Fab clone. C Binding specificity of the 12 candidate IgGs. The binding to different spike proteins (RBD, S1, S2, S protein trimer, and virion) was determined by ELISA Experiments were performed in duplicate, and the error bars denote $\pm \mathrm{SD}, \mathrm{n}=2$.

as a negative control, demonstrated no interaction with $\mathrm{S}$ protein (Fig. 2A and Supplementary Fig. S1A). Thus, all tested mAbs were suggested binding specifically to SARSCoV-2 S protein.

SPR assays were performed to evaluate the affinity of nine RBD-specific IgGs to S1 protein. F61, F163, H121, C25, H184, B110 and A199 showed a high affinity to S1 protein. The $K_{D}$ values ranged from $1.45 \times 10^{-12} \mathrm{~mol} / \mathrm{L}$ to $4.88 \times 10^{-12} \mathrm{~mol} / \mathrm{L}$. In comparison, lower $\mathrm{K}_{\mathrm{D}}$ values were detected regarding B15 and A8 (Fig. 2B and Supplementary Fig. S1B). Non-competitive ELISA assays were performed to evaluate the affinity of H278, B120 and H285 against $\mathrm{S} 2$ protein. The $\mathrm{K}_{\mathrm{D}}$ values of $\mathrm{H} 278, \mathrm{~B} 120$ and $\mathrm{H} 285$ 
Fig. 2 Characterizing the binding profile of candidate IgGs. A The specificity of SARS-CoV-2 specific IgGs detected by FACS. HEK 293 T cells expressing SARS-CoV-2 S protein were incubated with candidate $\mathrm{mAbs}$ or isotype $\mathrm{IgG}$ (HBV $\mathrm{mAb}$ ) and then stained with anti-human IgG FITCconjugated antibody.

Fluorescence intensity (FITC) negative cells was less than $10^{3}$, and that of positive cells was around $10^{4}$. B The affinity of candidate IgGs. The affinity between antibodies (F61, F163, B15, H121, C25, A8, H184, $\mathrm{B} 110$, and A199) and S1 was measured by BIAcore 8000 system. Non-competitive ELISA measured the affinity between mAbs (H278, B120, and $\mathrm{H} 285$ ) and $\mathrm{S} 2$.

C Neutralizing activity of candidate IgGs against SARS-

$\mathrm{CoV}-2$ pseudovirus and authentic SARS-CoV-2. Experiments were performed in duplicate, and the error bars denote $\pm \mathrm{SD}, \mathrm{n}=2$. The dashed line indicated a $50 \%$ reduction in viral infection.

\section{A}

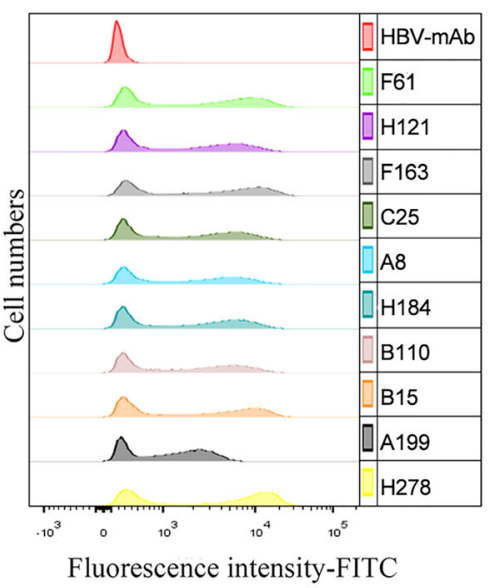

B

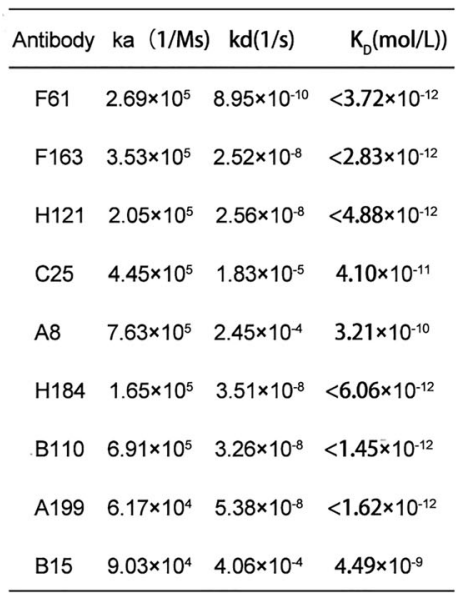

C
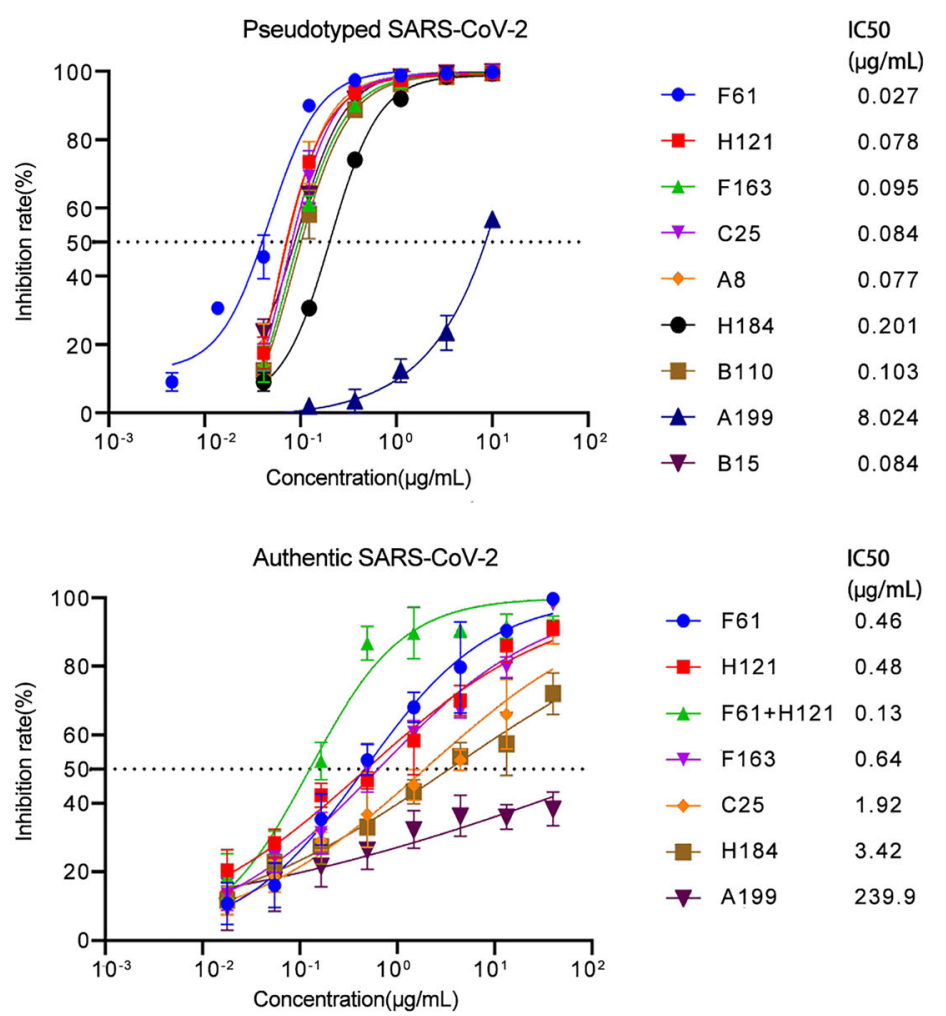

were $\quad 2.15 \times 10^{-11} \mathrm{~mol} / \mathrm{L}, \quad 2.6 \times 10^{-11} \mathrm{~mol} / \mathrm{L}$, $2.74 \times 10^{-11} \mathrm{~mol} / \mathrm{L}$, respectively (data not show).

Neutralizing capacity of 12 candidate IgGs was evaluated by authentic SARS-CoV-2 neutralization assay and pseudoviruses neutralization assay. F61, H121 and F163 exhibited high neutralizing capacity with IC50 of $0.46 \mu \mathrm{g} /$ $\mathrm{mL}, 0.48 \mu \mathrm{g} / \mathrm{mL}$, and $0.64 \mu \mathrm{g} / \mathrm{mL}$ to authentic SARSCoV-2, and $0.027 \mu \mathrm{g} / \mathrm{mL}, 0.078 \mu \mathrm{g} / \mathrm{mL}$, and $0.095 \mu \mathrm{g} / \mathrm{mL}$ to pseudoviruses, respectively. However, A199 exhibited low neutralizing capacity, which suggested not all RBDspecific antibodies were neutralizing antibodies. S2-specific mAbs failed to neutralize SARS-CoV-2 (data not shown). Moreover, the cocktail of F61 and H121 (at the ratio of $1: 1$ ) exhibited a synergistic neutralization to authentic SARS-CoV-2 with the neutralizing capacity $(0.13 \mu \mathrm{g} / \mathrm{mL})$ increased four times compared to each one alone (Fig. 2C).

To further characterize nine RBD-specific IgGs, we then analyzed antigenic epitopes of nine RBD-specific antibodies by competitive ELISA. Antibodies were roughly classified into three groups by competition percentages. Group one contained F61, F163, and B15. Group two included H121, C25, A8, B110, and H184. Group one and group two were not competitive, which suggested they 
bound to different antigenic epitopes. A199 from group three had no competition with mAbs in group one yet a partial competition with those from group two, suggesting that A199 bound to a non-neutralization epitope on RBD (Fig. 3A).

The inhibitory effect of these antibodies on the RBDACE2 interaction was investigated by FACS using ACE2 expressing HEK293T cells. F61 and F163 from group one showed no fluorescence signal from the antibody (FITC) or RBD (Taxes red), which suggested they may bind to an ACE2-competitive epitope to prevent RBD from binding to ACE2. B15 only partly blocked the binding of RBD to ACE2 due to its low affinity and neutralization capacity. In group two, H121, C25, A8, B110 and H184 failed to block the binding between RBD and ACE2, suggesting their epitopes were far from the ACE2-binding domain on RBD. A199 with low neutralizing capacity failed to block the binding between RBD and ACE2 either (Fig. 3B). Our results revealed that F61, F163 and B15 identified ACE2 competitive epitopes.

So far, we have obtained three types of antibodies. Group one is mainly represented by F61 and F163 which can recognize ACE2 receptor epitopes with high neutralization activity. One is represented by H121, which identifies epitopes not overlap with ACE2 binding sites, but has high neutralization activity. And the last one is A199, which binds to a non-overlapping epitope with ACE2 binding sites, and has no neutralization activity.

\begin{tabular}{|c|c|c|c|c|c|c|c|c|c|}
\hline \multirow[t]{2}{*}{ A } & \multicolumn{9}{|c|}{ Blocking Antibody } \\
\hline & F61 & F163 & B15 & $\mathrm{H} 121$ & $\mathrm{C} 25$ & A8 & B110 & H184 & A199 \\
\hline F61 & & 0.90 & 0.66 & 0.14 & 0.11 & 0.12 & 0.16 & 0.13 & 0.07 \\
\hline 容F163 & 0.81 & & 0.69 & 0.07 & 0.05 & 0.19 & 0.13 & 0.27 & 0.02 \\
\hline 。ㄹㄹㄹ & 0.79 & 0.78 & & 0.18 & 0.08 & 0.18 & 0.19 & 0.19 & 0.09 \\
\hline 岳 $\mathrm{H} 121$ & 0.07 & 0.05 & 0.10 & & 0.82 & 0.89 & 0.80 & 0.54 & 0.19 \\
\hline 竞 & 0.20 & 0.13 & 0.16 & 0.82 & & 0.90 & 0.84 & 0.67 & 0.07 \\
\hline$\stackrel{\nexists}{\triangle} \quad \mathrm{A} 8$ & 0.18 & 0.08 & 0.14 & 0.63 & 0.68 & & 0.70 & 0.53 & 0.17 \\
\hline B110 & 0.13 & 0.19 & 0.19 & 0.78 & 0.81 & 0.88 & & 0.51 & 0.13 \\
\hline H184 & 0.08 & 0.16 & 0.04 & 0.67 & 0.84 & 0.88 & 0.90 & & 0.11 \\
\hline A199 & 0.03 & 0.05 & 0.08 & 0.31 & 0.19 & 0.36 & 0.26 & 0.23 & \\
\hline
\end{tabular}
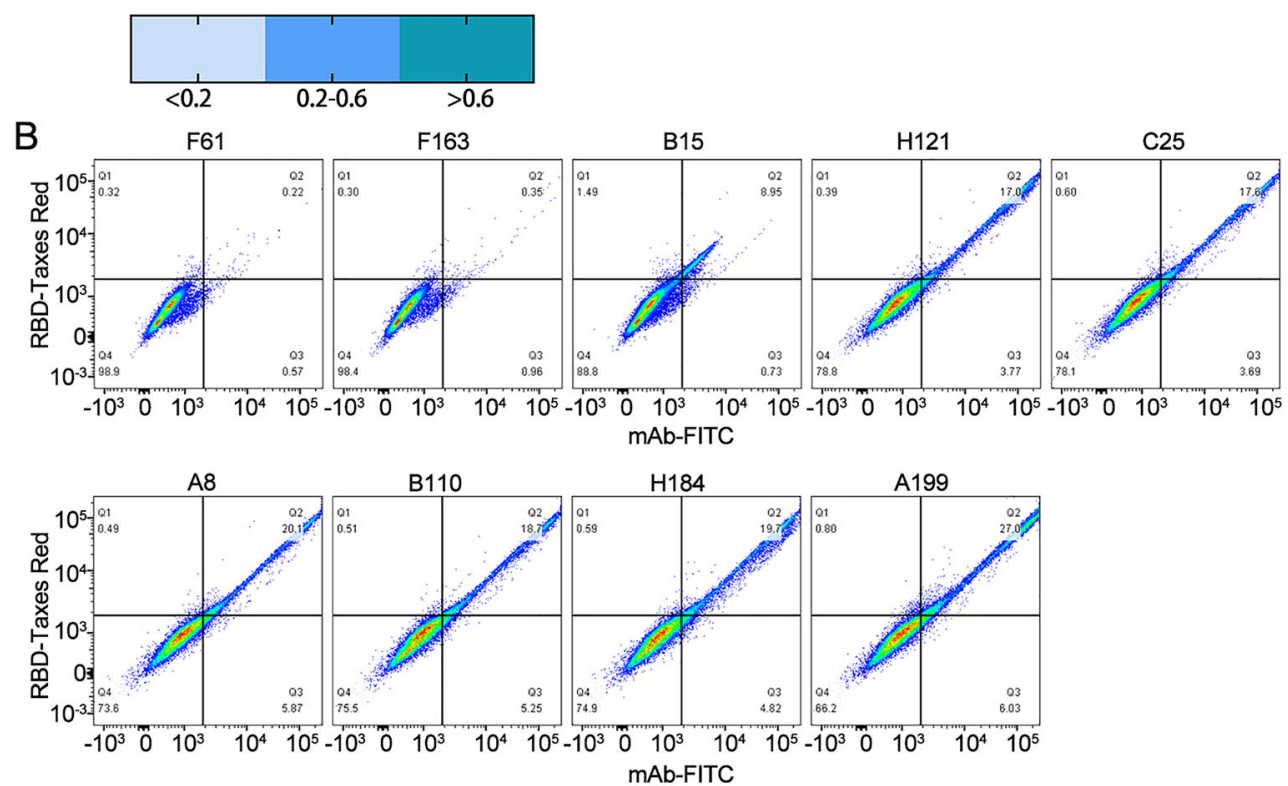

Fig. 3 Analysis of antibody epitopes by Competition ELISA assays and FACS. A Antigenic epitopes of nine RBD-specific IgGs were analyzed by competitive ELISA. Each lattice shows a competitive percentage. Values less than 0.20 indicated that the antibody has noncompetitive epitopes, the value between 0.20 and 0.60 indicated intermediate binding sites, and values greater than 0.60 indicated that the antibody shares overlapping or tight epitopes. B ACE2 binding block assay by FACS. The mouse-Fc tag Fusion protein of SARS-
CoV-2 RBD (RBD-mFC) was pre-incubated with nine RBD-specific IgGs or isotype IgG (HBV mAb) and then stained with HEK $293 \mathrm{~T}$ cells expressing ACE2. Anti-human (Fc) FITC-conjugated antibody and Anti-mouse $(\mathrm{Fc})$ Texas red-conjugated antibody were used as the secondary antibody. The $\mathrm{X}$-axis represented the fluorescence intensity of human antibodies labeled by FITC, and the Y-axis represented the fluorescence intensity of RBD-mFC labeled by Taxes red. 


\section{Interaction Between mAbs and RBD via Computer Modeling and Docking}

F61 and H121 exhibited a high neutralization capacity and bound to different epitopes. They were excellent candidates of antibody-based drugs to SARS-CoV-2. To precisely delineate the interaction between antibody and antigen. We further investigated the interaction between F61/H121 and RBD via computer simulation. Crystal structures that shared over $90 \%$ sequence similarity with F61 and H121 were used as the antibody template to build the 3D-structure of the two antibodies. Meanwhile, crystal structure 7DK3 (PDB) of SARS-CoV-2 RBD was used in the ZDOCK program and RDOCK program (Wrapp et al. 2020)

The outcomes demonstrated that F61 and H121 bind to diversified regions on RBD. F61 identified a linear epitope ranging from $\mathrm{G} 446$ to $\mathrm{S} 494$ on $\mathrm{RBD}$, involving 23 residues (Fig. 4A). Both the light and the heavy chain of F61 participated in binding to RBD. In specific, hydrogen-bond (H-bond) could be formed upon approaching RBD's P479, C480, N481 and F486 with D108, N37 and S109 on the F61's light chain, as well as F490 and L492 with G109 and R36, E484 with Y38 and Y114 on the heavy chain (Fig. 4B, upper panel). In comparison, H121 recognized a conformational epitope located remotely from the ACE2 binding region and mainly contributed by the heavy chain (Fig. 4A). Specifically, R355, G381 and L517 on RBD formed H-bond with S11A, N59 and Y109 residues on the heavy chain of H121 respectively. Both L518 and A520 on RBD can interact with Y37 on the heavy chain. R357 bond to Y38 on the light chain (Fig. 4B, lower panel).

The antibody-RBD complex structure was subsequently aligned with the ACE2-RBD complex based on the RBD sequence (Fig. 4C upper panel). Six residues within the F61 epitopes overlapped the ACE2-binding sites on the RBD. H121 positioned further away from the ACE2binding sites and hence showed no competitiveness in previous assays (Fig. 4C lower panel).

\section{Determination of the Effects of Natural Mutations in S Protein on the Sensitivity of Candidate Antibodies}

All S protein mutations (reported in the GISAID database up to 19 January 2021) were retrieved for analysis, with 333,251 sequences selected. Amino acid replacements, insertions, and deletions with a frequency exceeding $0.1 \%$ were focused on our project. Amongst all S protein mutations, D614G had the highest mutation frequency (94\%). Mutations in B.1.1.7 (including 69-70del, Y144del, N501Y, A570D, T716I, S982A, D1118H, and D614G) had a mutation frequency of around 5\%. In contrast, mutations in B.1.351 (D80A, D215G, 242-244del, R246I, K417N, E484K, N501Y, D614G, and A701V) had a much lower mutation frequency $(0.2 \%)$ (Fig. $5 \mathrm{~A}$ ).

The change of binding activity between IgGs and mutant S1 was evaluated by ELISA. The change of binding activity was defined by the value of OD 450 mutant $\mathrm{s} /$ OD450 wT s1. F61, F163, C25, H184 and B110 showed low sensitivity against single-residue variants with $\mathrm{A} 475 \mathrm{~V}$ and S477I. While, antibodies H121, C25, H184 and B110 exhibited a low sensitivity towards N354K, A348T, and A435S. Moreover, A199 exhibited a low sensitivity towards R246A and P384L (Fig. 5B).

The neutralizing activity of mAbs against pseudovirus with mutant $\mathrm{S}$ protein was evaluated via neutralization assay. The change of neutralizing activity was defined by the value of IC50 WT SARS-CoV-2 $/$ IC50 variant SARS-CoV-2. The ratio less than 0.25 was deemed as significant. Remarkably, F61 and F163 efficiently neutralized multiple mutations within RBD, including A475V and S477I which reduced the binding sensitivity of F61 and F163. H121, C25, A8 were evaluated to have low potencies against Q414E. Mutation L452R in India epidemic strain B.1.617 showed no resistance to F61 and H121, but reduced the neutralization sensitivity of C25, A8, H184, and B110 (Fig. 5C, 5D). Furthermore, we tested the neutralizing activity of F61 and H121 against variant strains B.1.1.7 and B.1.351. F61 and H121 exhibited efficient neutralizing activity against B.1.1.7, and slightly decreased but not significantly changed (ratio more than 0.25 ) neutralizing activity against B.1.351. Synergistic use of F61 and H121 exhibited similar neutralizing activities against the B.1.1.7, B.1.351, and WT virus (Fig. 5E).

\section{Discussion}

In this study, 12 SARS-CoV-2 specific IgGs were generated utilizing the Fab phage display library instead of the $\mathrm{scFv}$ phage library, which was used in some previous researches on antibodies selecting against the SARS-CoV2 (Noy-Porat et al. 2020; Bertoglio et al. 2021). Among the 12 selected antibodies, two of the RBD-specific antibodies (F61 and H121) had demonstrated high neutralizing activity and high affinity against SARS-CoV-2. However, three S2-specific antibodies and one RBD-specific antibody failed to neutralize SARS-CoV-2. Not all RBD-specific antibodies had the neutralizing capability. F61 identified a linear epitope located in residues G446-S494 which overlapped with ACE2 binding sites, and H121 recognized a conformational epitope located on the side face of RBD which could not block binding between RBD and ACE2. F61 and H121 maintained neutralizing activity against 

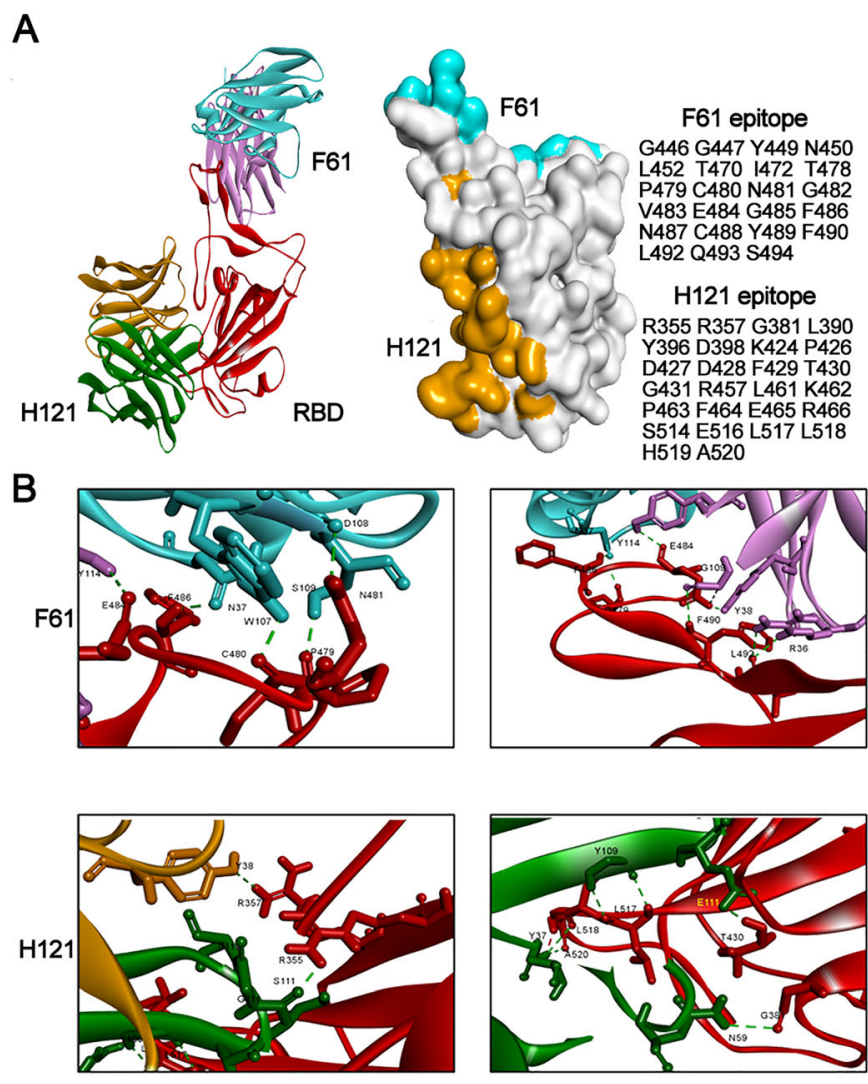

Fig. 4 Computer docking (ZDOCK) structure between F61/H121 and SARS-CoV-2 RBD. A ZDOCK structure of the RBD and antibodies complex was shown on the left. RBD was in red. F61 colored blue and pink. H121 was in orange and green. The complex of two antibodies and RBD were superimposed to demonstrate their relative positions and orientations. The footprint of F61 and H121 on RBD was shown in the middle. Blue and orange represent the footprint of F61 and H121, respectively. Binding residues were listed on the right. B The predicted Hydrogen-bond (H-bond) of F61 and H121. Green

B.1.1.7 and showed a slightly decreased but not significantly changed neutralizing activity against B.1.351. Synergistic use of F61 and H121 effectively neutralized B.1.1.7 and B.1.351. Hence F61 and H121 had broad neutralizing activity towards SARS-CoV-2 variants.

The receptor-binding motif (RBM) region (residues S438-Q506) on SARS-CoV-2 RBD consists of two short $\beta$ strands ( $\beta 5$ and $\beta 6$ ), two $\alpha$ helices ( $\alpha 4$ and $\alpha 5$ ) and loops, which contains most of the contacting residues of SARSCoV-2 that bind to ACE2 (Lan et al. 2020). The epitope of F61 was within this range. The structures of F61-RBD complex showed spatial conflict and epitope overlap between F61 and ACE2. FASC also confirmed that F61 effectively blocked the binding of RBD to ACE2. Therefore, F61 blocked viral infection by preventing ACE2 binding to SARS-CoV-2. H121 recognition epitope located on the side face of RBD which did not overlap with ACE2 binding sites. The neutralizing mechanism of H121 might similar to S309 and S2M11, which recognized an epitope
C

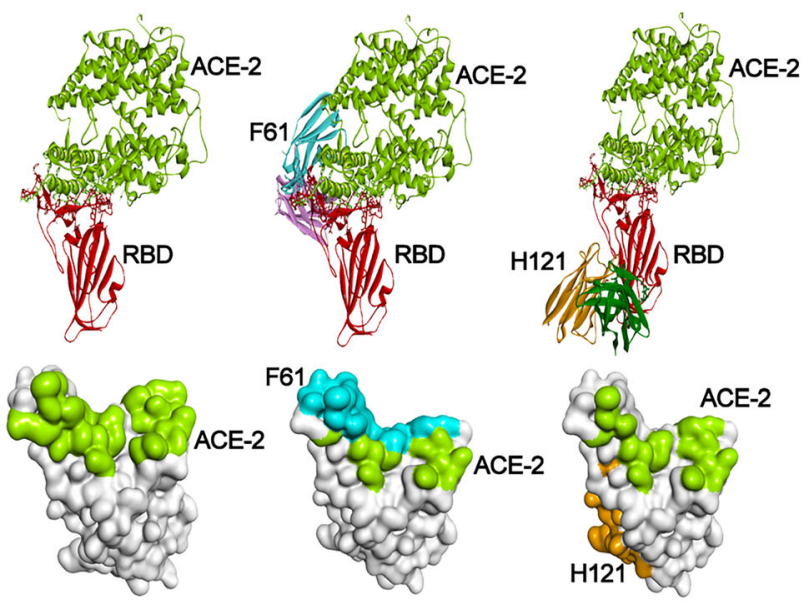

ACE-2 epitope ACE-2 binding residues K417 Y449 K453 L455 F456 F486 N487 Y489 Q493 G496 Q498 T500 N501 G502 Y505

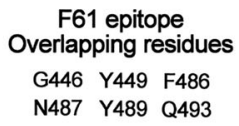

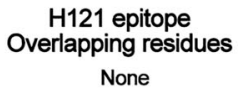

dashed lines indicated H-bond. The H-bond of F61 was shown on the upper panel. The H-bond of H121 was shown on the lower panel. C Epitopes were overlapping between the two antibodies and ACE2. The interaction between ACE2 and RBD was shown on the left. RBD was in red. ACE2 colored bright green. The interactions between ACE2, RBD and two antibodies were shown on the middle (F61) and left (H121). Color settings were consistent with those mentioned above. Overlapping residues between each of the antibodies and ACE2 were listed at the bottom.

outside of the ACE2 binding domain (Pinto et al. 2020; Tortorici et al. 2020). These two antibodies lock the S trimer in the closed state through binding to two neighboring RBDs within an $\mathrm{S}$ trimer. In this state, the RBM region is hidden and is inaccessible to ACE2 (Benton et al. 2020). Besides, N-terminal domain (NTD) specific antibodies, such as $4 \mathrm{~A} 8$ may neutralize SARS-CoV-2 by restraining the conformational changes of the $S$ protein (Chi et al. 2020). Neutralizing capacities of antibodies did not rely on their ability to block RBD-ACE2 interaction. Therefore, neutralizing antibodies protect cells from virus infection in various ways.

Variants of concern observed in the United Kingdom (B.1.1.7 with mutations N501Y), South Africa (B.1.351 with mutations K417N, E484K and N501Y), Brazil (P.1 with mutations K417T, E484K and N501Y) (Long et al. 2021) and India (B.1.617 with mutations L452R and E484Q) (Cherian et al. 2021) contain mutations K417N, L452R, A475V, E484K and N501Y. Pseudovirus with 
Fig. 5 Neutralization mutations of SARS-CoV-2 S protein and their effect on antibody neutralizing activity. A Amino acid mutations on $\mathrm{S}$ protein. Mutations in B.1.1.7 lineage were labeled red. Mutations in B.1.351 lineage were labeled blue. B The binding activity of RBD-specific IgGs between mutant $\mathrm{S} 1$ protein and wild-type (WT) S1 protein was detected by ELISA. The change of binding activity was defined by the ratio of OD 450 mutant $\mathrm{S}_{1} /$ OD $450_{\text {WT }}$ s1. The dashed line indicated that the ratio was less than 0.5 or more than 1.5 . The significant changes were marked red for decreased. C Neutralization activities of nine RBD-specific IgGs towards mutations on $\mathrm{S}$ protein were measured by pseudovirus.

D Neutralization activities of F61 and H121 towards mutations K417N, E484K, and N501Y on S protein were measured by pseudovirus. The IC50 value of F61 and H121 were $0.027 \mu \mathrm{g} / \mathrm{mL}, 0.078 \mu \mathrm{g} /$ $\mathrm{mL}$ against WT pseudotyped SARS-CoV-2. The changes in neutralization activity were shown in the ratio of IC50 between the variant and WT SARS-CoV-2 (GenBank: MN908947) (IC50 WT SARS-CoV${ }_{2} / \mathrm{IC} 50$ variant SARS-CoV-2). The ratio less than 1 indicated a reduced neutralization activity of the antibody against the variants and the ratio more than 1 indicated an increased neutralization activity. A difference by fourfold is considered significant (ratio more than 4 or less than 0.25 ). The changes were marked with colored symbols, red for decreased, blue for increased. E Neutralization activities of F61 and H121 towards B1.1.7 and B1.351 were measured by pseudovirus and authentic SARS-CoV-2. The IC50 value of F61 and H121 were $0.027 \mu \mathrm{g} / \mathrm{mL}, 0.078 \mu \mathrm{g} / \mathrm{mL}$ against WT pseudotyped SARS$\mathrm{CoV}-2$ and $0.46 \mu \mathrm{g} / \mathrm{mL}$, $0.48 \mu \mathrm{g} / \mathrm{mL}$ against WT authentic SARS-CoV-2. The $\mathrm{Y}$-axis represents the fold
A

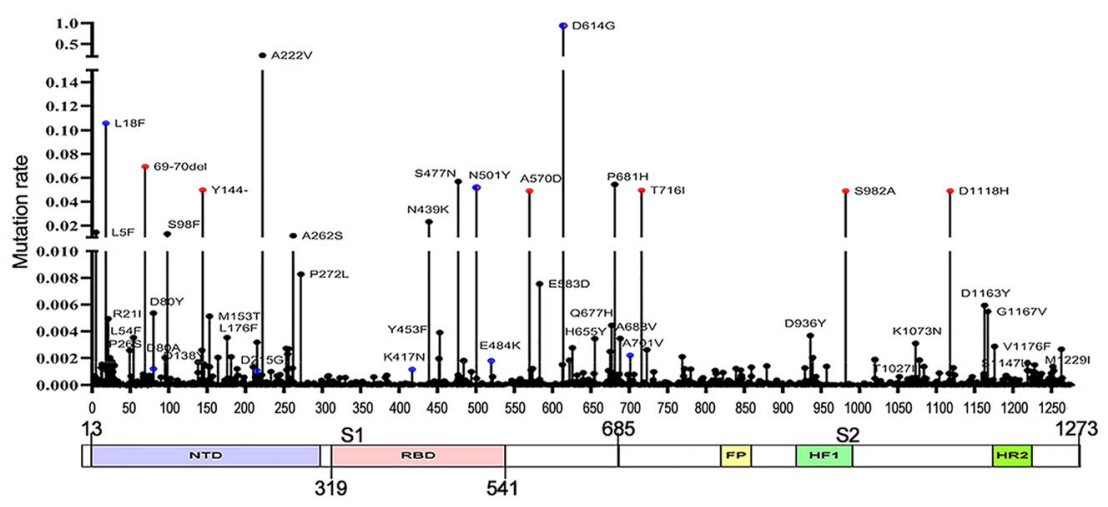

B
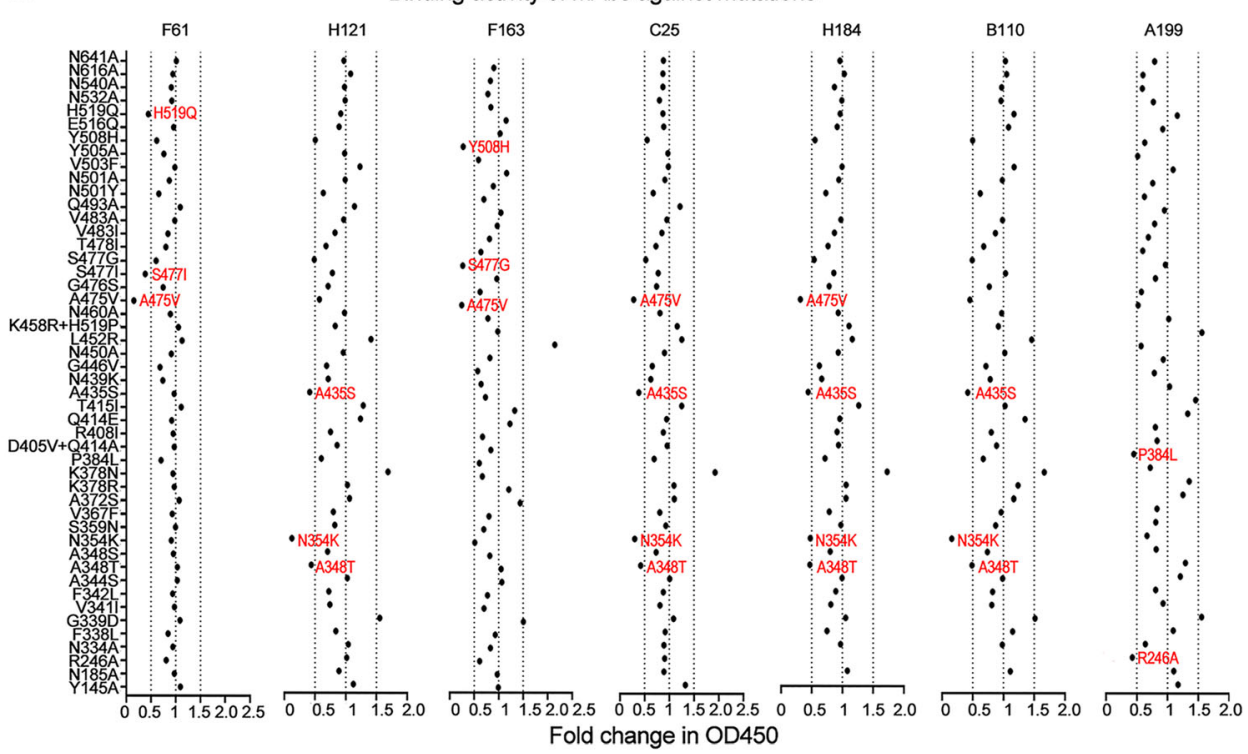

C

Fold change in IC 50 of mAbs against mutations
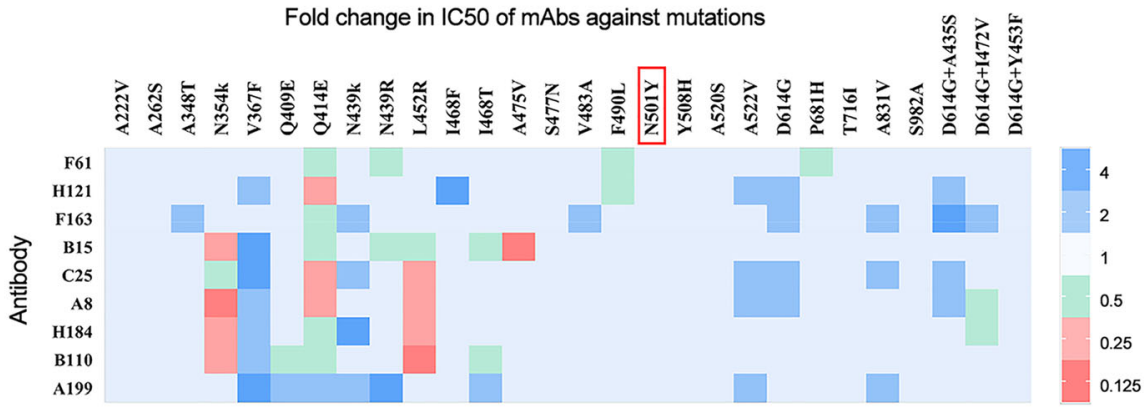

D

E
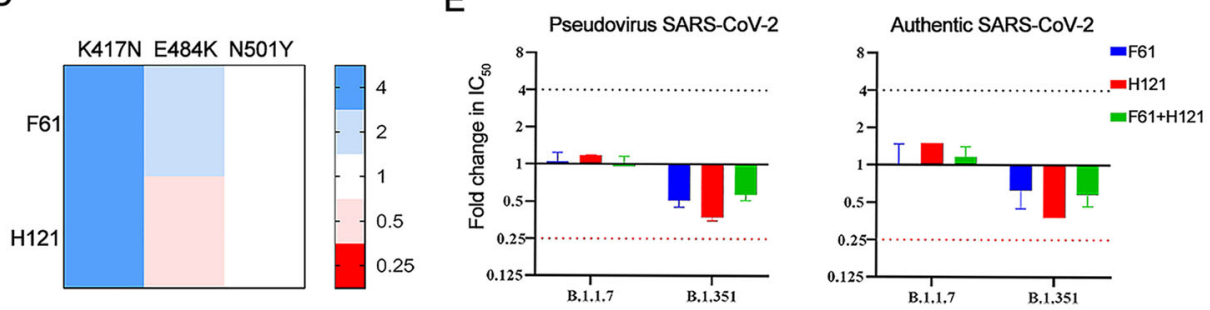
4 Fig. 5 caption continued: change of IC50 between the variant and WT SARS-CoV-2 (GenBank: MN908947) (IC50 WT SARS-CoV-2/IC50 variant SARS-CoV-2). The ratio less than 1 indicated a reduced neutralization activity of the antibody against the variants and the ratio more than 1 indicated an increased neutralization activity. A difference by fourfold is considered significant (ratio more than 4 or less than 0.25 ). The red dashed line indicated the ratio was less than 0.25 .

single-residue variants of K417N, L452R, A475V, E484K and $\mathrm{N} 501 \mathrm{Y}$ on $\mathrm{S}$ protein could be efficiently neutralized by F61 and H121. These results suggested that F61 and H121 had the potential to neutralize SARS-CoV-2 variants. B.1.1.7 and B.1.351 showed no resistance to F61 and H121. Variants P1 shared similar mutations to B.1.351. Mutation L452R carried by the Indian variants B.1.617 could also be effectively neutralized by F61 and H121. Hence we speculated that $\mathrm{P} 1$ and B.1.617 could also be neutralized by these two antibodies. F61 and H121 had broad neutralizing activity against variants.

South Africa variant B.1.351 show resistance to multiple neutralizing $\mathrm{mAbs}$ binding to ACE2 recognizing epitopes (Hoffmann et al. 2021; Widera et al. 2021), including three mAbs with emergency use authorization (EUA): REGN10933 (casirivimab), LY-CoV555 (bamlanivimab), and CB6 (etesevimab) (Kuzmina et al. 2021; Tada et al. 2021; Wang et al. 2021a; 2021c). However, both the pseudovirus and authentic SARS-CoV-2 neutralization assay showed that F61 and H121 could effectively neutralize the B.1.351. F61 identified a linear epitope ranging from residues G446 to $\mathrm{S} 494$ on $\mathrm{RBD}$, which included mutation site E484K in B.1.351. The linear epitope was considered more stable than the conformational epitope. Therefore, a single residue mutation within F61's epitope would barely alter the neutralizing activity of F61. Moreover, compared to CB6 (Shi et al. 2020), F61 had more residues in its binding interface on RBD. Antibodies covering more residues in the RDB binding interface might have a higher tolerance to viral mutations (Li et al. 2021). H121 recognized an epitope on a side face of RBD which remote from the ACE2 binding region. Mutations K417N, E484K and N501Y in B.1.351 were not within the H121 epitope, therefore B.1.351 showed no resistance to the neutralizing activity of H121. In addition, F61 and H121 bound to non-overlapping regions of the RBD and masked more epitopes on RBD. Occupying more neutral epitopes could prevent virus escape (Piccoli et al. 2020). Revealed in our study, the cocktail of F61 and H121 effectively neutralized B.1.1.7, B.1.351 and WT SARS-CoV-2. Hence synergistic use of antibodies with different epitopes could improve the treatment efficacy by mitigating viral escape (Wang et al. 2021b), and should be investigated for developing future therapy.
While designing antibody-based, efficient biological drugs, it is essential to precisely delineate the interaction between antibody and antigen structures. X-ray crystallography and cryo-electron microscopy (cryo-EM) are common methods for crystal structural analysis, which require high experimental conditions. Antibodies have a highly conserved framework, hence compute homology models building for antibodies can be reasonably accurate (Yamashita et al. 2014; Leem et al. 2016). Based on the crystal structure of SARS-CoV-2 RBD in the PDB database, the computer docking technique can accurately predict the structure of antibodies and RBD. Thus we chose computer simulation to analyze antibody-antigen interaction. The ZDOCK method used in this study, a rigid-body docking algorithm based on fast Fourier transforms (FFTs) (Pierce et al. 2014), does not consider possible conformational changes, causing possible deviation in docking results. Therefore, we will consider semi-flexible docking protocols accounting for protein flexibility, such as HADDOCK (van Zundert et al. 2016), and dynamic simulation methods for further model optimizations.

Succinctly, two antibodies (F61 and H121) obtained within our study were demonstrated with high affinity and high-neutralizing activity against distinct RBD epitopes. Meanwhile, evidence generated during our screening indicated that not all RBD-specific antibodies were capable of performing neutralization. In comparison, antibodies could neutralize SARS-CoV-2 without necessarily blocking the binding of RBD to ACE-2. Neutralizing activity of F61 and H121 was maintained when tested against multiple mutations and variants B.1.1.7 and B.1.351. Furthermore, the unchanged neutralizing activity to N501Y, E484K, and L452R indicated that the gained antibodies may also neutralize the recent India endemic strain B.1.617, which revealed a broad neutralizing activity against SARS-CoV-2 variants. Our findings provided promising candidate antibodies to clinical treatment of SARS-Cov-2 variants and contributed a two-antibody cocktail therapy against constantly emerging variants.

Acknowledgements We thank Professor Xuanling Shi from Tsinghua University for her technical help in human antibody expression; Dr. Tingyou Chen and his research team from INNOVITA for supporting antibody detection reagents of SARS-CoV-2; Dr. Huawei Wei from Jiangsu East-Mab Biomedical Technology for his advice in high-yield antibody expressing; Dr. WenqiAn from Hualan Biological Engineering for his technical help in performing SPR. This work was supported by the National Science and Technology Major Project (2018ZX10711-001) (2017YFA0205100).

Author Contributions YQ and LS performed the experiments and wrote the paper; XZ and ZC performed all works in BSL3 facilities; MW analyzed mutational epitopes, YJ and XJ collected COVID-19 patients samples and analysis, CL (Fudan University), QY, YL, WW, and CL (IVDC, China CDC) assisted the laboratory experiment; JL and TY analyzed the data; DL, FZ, and YW supervised and discussed 
the data; ML, SW, and WG designed the project and edited the manuscript. All authors read and approved the final manuscript.

\section{Compliance with Ethical Standards}

Conflict of interest The authors declare that they have no conflict of interest.

Animal and Human Rights Statement This article does not contain any studies with human or animal subjects performed by any of the authors.

\section{References}

Barbas CF, Burton DR (1996) Selection and evolution of high-affinity human anti-viral antibodies. Trends Biotechnol 14:230-234

Barbas CF, Kang AS, Lerner RA, Benkovic SJ (1991) Assembly of combinatorial antibody libraries on phage surfaces: the gene III site. Proc Natl Acad Sci U S A 88:7978-7982

Barnes CO, Jette CA, Abernathy ME, Dam KA, Esswein SR, Gristick HB, Malyutin AG, Sharaf NG, Huey-Tubman KE, Lee YE, Robbiani DF, Nussenzweig MC, West AP Jr, Bjorkman PJ (2020) SARS-CoV-2 neutralizing antibody structures inform therapeutic strategies. Nature 588:682-687

Benton DJ, Wrobel AG, Xu P, Roustan C, Martin SR, Rosenthal PB, Skehel JJ, Gamblin SJ (2020) Receptor binding and priming of the spike protein of SARS-CoV-2 for membrane fusion. Nature 588:327-330

Bertoglio F, Meier D, Langreder N, Steinke S, Rand U, Simonelli L, Heine PA, Ballmann R, Schneider KT, Roth KDR, Ruschig M, Riese P, Eschke K, Kim Y, Schäckermann D, Pedotti M, Kuhn P, Zock-Emmenthal S, Wöhrle J, Kilb N, Herz T, Becker M, Grasshoff M, Wenzel EV, Russo G, Kröger A, Brunotte L, Ludwig S, Fühner V, Krämer SD, Dübel S, Varani L, Roth G, Čičin-Šain L, Schubert M, Hust M (2021) SARS-CoV-2 neutralizing human recombinant antibodies selected from prepandemic healthy donors binding at RBD-ACE2 interface. Nature Commun 12:1577

Cherian S, Potdar V, Jadhav S, Yadav P, Gupta N, Das M, Rakshit P, Singh S, Abraham P, Panda S (2021) Convergent evolution of SARS-CoV-2 spike mutations, L452R, E484Q and P681R, in the second wave of COVID-19 in Maharashtra. India Biorxiv. https://doi.org/10.1101/2021.2004.2022.440932

Chi X, Renhong Y, Zhang J, Zhang GY, Zhang YY, Hao M, Zhang Z, Fan PF, Dong YZ, Yang YL, Chen Z, Guo YY, Zhang JL, Li Y, Song X, Chen Y, Xia L, Fu L, Hou L, Xu J, Yu C, Li J, Zhou Q, Chen W (2020) A neutralizing human antibody binds to the N-terminal domain of the Spike protein of SARS-CoV-2. Science 369:650-655

Ge J, Wang R, Ju B, Zhang Q, Sun J, Chen P, Zhang S, Tian Y, Shan S, Cheng L, Zhou B, Song S, Zhao J, Wang H, Shi X, Ding Q, Liu L, Zhao J, Zhang Z, Wang X, Zhang L (2021) Antibody neutralization of SARS-CoV-2 through ACE2 receptor mimicry. Nature Commun 12:250

Hoffmann M, Arora P, Groß R, Seidel A, Hörnich B, Hahn A, Krüger N, Graichen L, Hofmann-Winkler H, Kempf A, Winkler MS, Schulz S, Jäck H-M, Jahrsdörfer B, Schrezenmeier H, Müller M, Kleger A, Münch J, Pöhlmann S (2021) SARS-CoV-2 variants B.1.351 and B.1.1.248: escape from therapeutic antibodies and antibodies induced by infection and vaccination. BioRxiv. https://doi.org/10.1101/2021.2002.2011.430787

Hwang WC, Lin Y, Santelli E, Sui J, Jaroszewski L, Stec B, Farzan M, Marasco WA, Liddington RC (2006) Structural basis of neutralization by a human anti-severe acute respiratory syndrome spike protein antibody, 80R. J Biol Chem 281:34610-34616

Ju B, Zhang Q, Ge J, Wang R, Sun J, Ge X, Yu J, Shan S, Zhou B, Song S, Tang X, Yu J, Lan J, Yuan J, Wang H, Zhao J, Zhang S, Wang Y, Shi X, Liu L, Zhao J, Wang X, Zhang Z, Zhang L (2020) Human neutralizing antibodies elicited by SARS-CoV-2 infection. Nature 584:115-119

Kashyap AK, Steel J, Oner AF, Dillon MA, Swale RE, Wall KM, Perry KJ, Faynboym A, Ilhan M, Horowitz M, Horowitz L, Palese P, Bhatt RR, Lerner RA (2008) Combinatorial antibody libraries from survivors of the Turkish H5N1 avian influenza outbreak reveal virus neutralization strategies. Proc Natl Acad Sci USA 105:5986-5991

Kaushik S, Sowdhamini R (2011) Structural analysis of prolyl oligopeptidases using molecular docking and dynamics: insights into conformational changes and ligand binding. PLoS ONE 6:e26251

Kuzmina A, Khalaila Y, Voloshin O, Keren-Naus A, Bohehm L, Raviv Y, Shemer-Avni Y, Rosenberg E, Taube R (2021) SARS CoV-2 escape variants exhibit differential infectivity and neutralization sensitivity to convalescent or post-vaccination sera. MedRxiv. https://doi.org/10.1101/2021.02.22.21252002

Laffeber C, de Koning K, Kanaar R, Lebbink JHG (2021) Experimental evidence for enhanced receptor binding by rapidly spreading SARS-CoV-2 variants. bioRxivdoi: https://doi.org/10. 1101/2021.02.22.432357

Lan J, Ge J, Yu J, Shan S, Zhou H, Fan S, Zhang Q, Shi X, Wang Q, Zhang L, Wang X (2020) Structure of the SARS-CoV-2 spike receptor-binding domain bound to the ACE2 receptor. Nature 581:215-220

Leem J, Dunbar J, Georges G, Shi J, Deane CM (2016) ABodyBuilder: automated antibody structure prediction with datadriven accuracy estimation. Mabs 8:1259-1268

Li Q, Wu J, Nie J, Zhang L, Hao H, Liu S, Zhao C, Zhang Q, Liu H, Nie L, Qin H, Wang M, Lu Q, Li X, Sun Q, Liu J, Zhang L, Li X, Huang W, Wang Y (2020) The impact of mutations in SARSCoV-2 spike on viral infectivity and antigenicity. Cell 182:12841294.e9

Li Q, Nie J, Wu J, Zhang L, Ding R, Wang H, Zhang Y, Li T, Liu S, Zhang M, Zhao C, Liu H, Nie L, Qin H, Wang M, Lu Q, Li X, Liu J, Liang H, Shi Y, Shen Y, Xie L, Zhang L, Qu X, Xu W, Huang W, Wang Y (2021) SARS-CoV-2 501Y.V2 variants lack higher infectivity but do have immune escape. Cell 184:2362-2371

Liu L, Wang P, Nair MS (2020) Potent neutralizing antibodies against multiple epitopes on SARS-CoV-2 spike. Nature 584:450-456

Long SW, Olsen RJ, Christensen PA, Subedi S, Olson R, Davis JJ, Saavedra MO, Yerramilli P, Pruitt L, Reppond K, Shyer MN, Cambric J, Finkelstein IJ, Gollihar J, Musser JM (2021) Sequence analysis of 20,453 SARS-CoV-2 genomes from the houston metropolitan area identifies the emergence and widespread distribution of multiple isolates of all major variants of concern. Am J Pathol. https://doi.org/10.1016/j.ajpath.2021.03. 004

Nie J, Li Q, Wu J, Zhao C, Hao H, Liu H, Zhang L, Nie L, Qin H, Wang M, Lu Q, Li X, Sun Q, Liu J, Fan C, Huang W, Xu M, Wang Y (2020) Establishment and validation of a pseudovirus neutralization assay for SARS-CoV-2. Emerg Microbes Infect 9:680-686

Noy-Porat T, Makdasi E, Alcalay R, Mechaly A, Levy Y, BercovichKinori A, Zauberman A, Tamir H, Yahalom-Ronen Y, Israeli M, Epstein E, Achdout H, Melamed S, Chitlaru T, Weiss S, Peretz E, Rosen O, Paran N, Yitzhaki S, Shapira SC, Israely T, Mazor O, Rosenfeld R (2020) A panel of human neutralizing mAbs 
targeting SARS-CoV-2 spike at multiple epitopes. Nat Commun 11:4303

Piccoli L, Park YJ, Tortorici MA, Czudnochowski N, Walls AC, Beltramello M, Silacci-Fregni C, Pinto D, Rosen LE, Bowen JE, Acton OJ, Jaconi S, Guarino B, Minola A, Zatta F, Sprugasci N, Bassi J, Peter A, De Marco A, Nix JC, Mele F, Jovic S, Rodriguez BF, Gupta SV, Jin F, Piumatti G, Lo Presti G, Pellanda AF, Biggiogero M, Tarkowski M, Pizzuto MS, Cameroni E, Havenar-Daughton C, Smithey M, Hong D, Lepori V, Albanese E, Ceschi A, Bernasconi E, Elzi L, Ferrari P, Garzoni C, Riva A, Snell G, Sallusto F, Fink K, Virgin HW, Lanzavecchia A, Corti D, Veesler D (2020) Mapping neutralizing and immunodominant sites on the SARS-CoV-2 spike receptor-binding domain by structure-guided high-resolution serology. Cell 183:1024-1042.e1021

Pierce BG, Wiehe K, Hwang H, Kim BH, Vreven T, Weng Z (2014) ZDOCK server: interactive docking prediction of protein-protein complexes and symmetric multimers. Bioinformatics 30:1771-1773

Pinto D, Park YJ, Beltramello M, Walls AC, Tortorici MA, Bianchi S, Jaconi S, Culap K, Zatta F, De Marco A, Peter A, Guarino B, Spreafico R, Cameroni E, Case JB, Chen RE, Havenar-Daughton C, Snell G, Telenti A, Virgin HW, Lanzavecchia A, Diamond MS, Fink K, Veesler D, Corti D (2020) Cross-neutralization of SARS-CoV-2 by a human monoclonal SARS-CoV antibody. Nature 583:290-295

Shi R, Shan C, Duan X, Chen Z, Liu P, Song J, Song T, Bi X, Han C, Wu L, Gao G, Hu X, Zhang Y, Tong Z, Huang W, Liu WJ, Wu G, Zhang B, Wang L, Qi J, Feng H, Wang FS, Wang Q, Gao GF, Yuan Z, Yan J (2020) A human neutralizing antibody targets the receptor-binding site of SARS-CoV-2. Nature 584:120-124

Starr TN, Greaney AJ, Hilton SK, Ellis D, Crawford KHD, Dingens AS, Navarro MJ, Bowen JE, Tortorici MA, Walls AC, King NP, Veesler D, Bloom JD (2020) Deep mutational scanning of SARS-CoV-2 receptor binding domain reveals constraints on folding and ACE2 binding. Cell 182:1295-1310.e1220

Tada T, Dcosta BM, Zhou H, Vaill A, Kazmierski W, Landau NR (2021) Decreased neutralization of SARS-CoV-2 global variants by therapeutic anti-spike protein monoclonal antibodies. BioRxiv. https://doi.org/10.1101/2021.02.18.431897

Thomson EC, Rosen LE, Shepherd JG, Spreafico R, da Silva FA, Wojcechowskyj JA, Davis C, Piccoli L, Pascall DJ, Dillen J, Lytras S, Czudnochowski N, Shah R, Meury M, Jesudason N, De Marco A, Li K, Bassi J, O'Toole A, Pinto D, Colquhoun RM, Culap K, Jackson B, Zatta F, Rambaut A, Jaconi S, Sreenu VB, Nix J, Zhang I, Jarrett RF, Glass WG, Beltramello M, Nomikou K, Pizzuto M, Tong L, Cameroni E, Croll TI, Johnson N, Di Iulio J, Wickenhagen A, Ceschi A, Harbison AM, Mair D, Ferrari P, Smollett K, Sallusto F, Carmichael S, Garzoni C, Nichols J, Galli M, Hughes J, Riva A, Ho A, Schiuma M, Semple MG, Openshaw PJM, Fadda E, Baillie JK, Chodera JD, Rihn SJ, Lycett SJ, Virgin HW, Telenti A, Corti D, Robertson DL, Snell G (2021) Circulating SARS-CoV-2 spike N439K variants maintain fitness while evading antibody-mediated immunity. Cell 184:1171-1187.e1120

Tian F, Tong B, Sun L, Shi S, Zheng B, Wang Z, Dong X, Zheng P (2021) Mutation N501Y in RBD of spike protein strengthens the interaction between COVID-19 and its receptor ACE2. BioRxiv. https://doi.org/10.1101/2021.02.14.431117

Tortorici MA, Beltramello M, Lempp FA, Pinto D, Dang HV, Rosen LE, McCallum M, Bowen J, Minola A, Jaconi S, Zatta F, De Marco A, Guarino B, Bianchi S, Lauron EJ, Tucker H, Zhou J, Peter A, Havenar-Daughton C, Wojcechowskyj JA, Case JB, Chen RE, Kaiser H, Montiel-Ruiz M, Meury M, Czudnochowski N, Spreafico R, Dillen J, Ng C, Sprugasci N, Culap K, Benigni F, Abdelnabi R, Foo SC, Schmid MA, Cameroni E, Riva A,
Gabrieli A, Galli M, Pizzuto MS, Neyts J, Diamond MS, Virgin HW, Snell G, Corti D, Fink K, Veesler D (2020) Ultrapotent human antibodies protect against SARS-CoV-2 challenge via multiple mechanisms. Science 370:950-957

van Zundert GCP, Rodrigues J, Trellet M, Schmitz C, Kastritis PL, Karaca E, Melquiond ASJ, van Dijk M, de Vries SJ, Bonvin A (2016) The HADDOCK2.2 web server: user-friendly integrative modeling of biomolecular complexes. J Mol Biol 428:720-725

Wang L, Zhou T, Zhang Y, Yang ES, Schramm CA, Shi W, Pegu A, Oloninyi OK, Ransier A, Darko S, Narpala SR, Hatcher C, Martinez DR, Tsybovsky Y, Phung E, Abiona OM, Cale EM, Chang LA, Corbett KS, DiPiazza AT, Gordon IJ, Leung K, Liu T, Mason RD, Nazzari A, Novik L, Olia AS, Stephens T, Stringham CD, Talana CA, Teng IT, Wagner D, Widge AT, Zhang B, Roederer M, Ledgerwood JE, Ruckwardt TJ, Gaudinski MR, Baric RS, Graham BS, McDermott AB, Douek DC, Kwong PD, Mascola JR, Sullivan NJ, Misasi J (2021a) Antibodies with potent and broad neutralizing activity against antigenically diverse and highly transmissible SARS-CoV-2 variants. BioRxiv. https://doi.org/10.1101/2021.02.25.432969

Wang N, Sun Y, Feng R, Wang Y, Guo Y, Zhang L, Deng YQ, Wang L, Cui Z, Cao L, Zhang YJ, Li W, Zhu FC, Qin CF, Wang X (2021b) Structure-based development of human antibody cocktails against SARS-CoV-2. Cell 31:101-103

Wang P, Liu L, Iketani S, Luo Y, Guo Y, Wang M, Yu J, Zhang B, Kwong PD, Graham BS, Mascola JR, Chang JY, Yin MT, Sobieszczyk M, Kyratsous CA, Shapiro L, Sheng Z, Nair MS, Huang Y, Ho DD (2021c) Increased resistance of SARS-CoV-2 variants B.1.351 and B.1.1.7 to antibody neutralization. BioRxiv. https://doi.org/10.1101/2021.01.25.428137

Wec A, Wrapp D, Herbert A, Maurer D, Haslwanter D, Sakharkar M, Jangra R, Dieterle M, Lilov A, Huang D, Tse L, Johnson N, Hsieh C, Wang N, Nett J, Champney E, Burnina I, Brown M, Lin S, Sinclair M, Johnson C, Pudi S, Rr B, Wirchnianski A, Laudermilch E, Florez C, Fels J, O’Brien C, Graham B, Nemazee D, Burton D, Baric R, Voss J, Chandran K, Dye J, McLellan J, Walker L (2020) Broad neutralization of SARSrelated viruses by human monoclonal antibodies. Science 369:731-736

Widera M, Wilhelm A, Hoehl S, Pallas C, Kohmer N, Wolf T, Rabenau HF, Corman V, Drosten C, Vehreschild MJGT, Goetsch U, Gottschalk R, Ciesek S (2021) Bamlanivimab does not neutralize two SARS-CoV-2 variants carrying E484K in vitro. BioRxiv. https://doi.org/10.1101/2021.02.24.21252372

World Health Organization (WHO) Weekly epidemiological update on COVID-19 - 4 May 2021. https://www.who.int/publications/ $\mathrm{m} /$ item/weekly-epidemiological-update-on-covid-19-4-may2021. Accessed 4 May 2021

Wrapp D, Wang N, Corbett KS, Goldsmith JA, Hsieh CL, Abiona O, Graham BS, McLellan JS (2020) Cryo-EM structure of the 2019-nCoV spike in the prefusion conformation. Science 367:1260-1263

Wu Y, Wang F, Shen C, Peng W, Li D, Zhao C, Li Z, Li S, Bi Y, Yang Y, Gong Y, Xiao H, Fan Z, Tan S, Wu G, Tan W, Lu X,Fan C, Wang Q, Liu Y, Zhang C, Qi J, Gao G, Gao F, Liu L (2020) A noncompeting pair of human neutralizing antibodies block COVID-19 virus binding to its receptor ACE2. Science 368:1274-1278

Xiang Y, Nambulli S, Xiao Z, Liu H, Sang Z, Duprex WP, Schneidman-Duhovny D, Zhang C, Shi Y (2020) Versatile, multivalent nanobody cocktails efficiently neutralize SARSCoV-2. BioRxiv. https://doi.org/10.1101/2020.08.24.264333

Yadav PD, Sapkal GN, Abraham P, Ella R, Deshpande G, Patil DY, Nyayanit DA, Gupta N, Sahay RR, Shete AM, Panda S, Bhargava B, Mohan VK (2021) Neutralization of variant under 
investigation B.1.617 with sera of BBV152 vaccinees. BioRxiv. https://doi.org/10.1101/2021.04.23.441101

Yamashita K, Ikeda K, Amada K, Liang S, Tsuchiya Y, Nakamura H, Shirai H, Standley DM (2014) Kotai antibody builder: automated high-resolution structural modeling of antibodies. Bioinformatics 30:3279-3280

Yao W, Wang Y, Ma D, Tang X, Wang H, Li C, Lin H, Li Y, Zhong G (2021) Spike mutations decrease SARS-CoV-2 sensitivity to neutralizing antibodies but not ACE2-Ig in vitro. BioRxiv. https://doi.org/10.1101/2021.01.27.428353
Zhang L, Jackson CB, Mou H, Ojha A, Rangarajan ES, Izard T, Farzan M, Choe H (2020) The D614G mutation in the SARS$\mathrm{CoV}-2$ spike protein reduces $\mathrm{S} 1$ shedding and increases infectivity. BioRxiv. https://doi.org/10.1101/2020.06.12.148726

Zhou P, Yang XL, Wang XG, Hu B, Zhang L, Zhang W, Si HR, Zhu Y, Li B, Huang CL, Chen HD, Chen J, Luo Y, Guo H, Jiang RD, Liu MQ, Chen Y, Shen XR, Wang X, Zheng XS, Zhao K, Chen QJ, Deng F, Liu LL, Yan B, Zhan FX, Wang YY, Xiao GF, Shi ZL (2020) A pneumonia outbreak associated with a new coronavirus of probable bat origin. Nature 579:270-273 